\title{
Streekromans en het Tsjechische ruralisme ${ }^{1}$
}

\author{
WILKEN ENGELBRECHT \\ Palacký University Olomouc \\ Katedra nederlandistiky FF \\ Univerzita Palackého \\ Křižkovského 10 \\ CZ-77180 Olomouc, Czech Republic \\ wilken.engelbrecht@upol.cz
}

\section{Regional Novels and the Czech Ruralism}

\begin{abstract}
In the Netherlands regional novels have never been considered as real literary works. In Flanders regional literature had a better status, especially because several writers of the Van Nu en Straks movement such as Stijn Streuvels wrote about regional themes. In Czech literature since 1848 regional themes was viewed as important in novels and stories, mainly till the end of World War II. In 1932 the Catholic writer Antonín Matula defined the so-called Ruralism, which became a movement of mainly Catholic writers from the countryside. Most of them were severely persecuted in a constructed Stalinist show trial against the Green International in 1951. In his work Hlasy země v evropských literaturách (The Voice of Earth in European Literatures, 1933) Matula discussed nearly all major European literatures, i.e. Flemish regional writers. It is no coincidence that especially Flemish writers such as Ernest Claes, Stijn Streuvels and Felix Timmermans, were translated into Czech during the second quarter of the $20^{\text {th }}$ century.
\end{abstract}

Keywords: regional novels; ruralism; Dutch literature; Flemish literature; Czech translation; Antonín Matula; Green International; communist persecution

\footnotetext{
${ }^{1}$ Bij het samenstellen van deze bijdrage is gebruik gemaakt van onderzoeksresultaten van de projectsubsidies P406/12/0351 Dějiny nizozemské a vlámské literatury van de Grant Agency of the Czech Republic en OLOMOU(117)/MR/rv Receptie van Nederlandstalige literatuur in het Tsjechisch tussen 1848 en 1948 van de Nederlandse Taalunie.
} 


\section{Inleiding}

Vanuit een Nederlandse optiek zijn schrijvers van streekromans als Antoon Coolen en A. den Doolaard nooit voor vol aangezien. Er woedde in Nederland in 1938 zelfs een heus regionalismedebat met Menno ter Braak, Theun de Vries en Antoon Coolen als hoofdrolspelers. ${ }^{2}$ Binnen de literatuur in Vlaanderen was de erkenning van schrijvers van streekromans groter, omdat ook voormannen van Van Nu en Straks als Cyriel Buysse en Stijn Streuvels zich met dit genre hebben beziggehouden. ${ }^{3}$

Voor de Tsjechische literatuur was het ruralisme (ruralismus) in elk geval in het interbellum een erkende literaire stroming. ${ }^{4}$ Schrijvers als Jan Čep, Václav Renč en in iets mindere mate Václav Prokůpek waren bekende en erkende auteurs. Het ruralisme kwam na de communistische machtsovername van 1948 in het diskrediet, omdat de thematiek inging tegen de communistische pogingen om de landbouw te collectiviseren.

Gegeven de positie van het ruralisme in het interbellum is het niet zo verwonderlijk dat er toen veel streekromans van Nederlandstalige herkomst in het Tsjechisch werden vertaald. Zo treffen we zo'n vijftien titels aan met werken van Ernest Claes, Antoon Coolen, A. den Doolaard, Herman de Man en Felix Timmermans, tijdens Wereldoorlog II nog aangevuld met ruim twintig andere streekromans, waaronder een goede keuze van het werk van Streuvels. Opmerkelijk is dat het merendeel van deze romans rechtstreeks uit het Nederlands werd vertaald. Dit is te danken aan het feit dat de vertalers van het grootste deel van de romans, Lída Faltová, Rudolf J. Vonka en Milada Šimsová allen goed Nederlands kenden en in principe rechtstreeks vanuit het Nederlands vertaalden. ${ }^{5}$ Van de genoemden waren Coolen en Timmermans gegeven de vele herdrukken duidelijk het populairste bij het Tsjechische lezerspubliek. Opmerkelijk is dat veel vertalingen van Nederlandstalige streekromans vlak na de oorlog tijdens de Stalinistische periode van het communisme in herdrukken of nieuwe uitgaven konden uitkomen, terwijl de eigen ruralistische auteurs al werden onderdrukt of soms zelfs regelrecht vervolgd. Bij de zuiveringen van de openbare en wetenschappelijke bibliotheken

\footnotetext{
${ }^{2}$ Dit debat werd gedeeltelijk gereconstrueerd door Van Faassen 2003.

${ }^{3}$ Zie de illustratieve inleiding van De Geest e.a. in het themanummer over streekliteratuur van Spiegel der Letteren 47 (2005), nr. 2, p. 89-98.

${ }^{4}$ Men vergelijke bijv. in de beknopte Tsjechische literatuurgeschiedenis van Novák 1946: 670-678. Een goede recente inleiding in de problematiek geeft Hora 2009.

${ }_{5}^{5}$ Gegevens op basis van Krijtová e.a. 1993, aangevuld met eigen onderzoek. Van de vertalingen zijn alleen die van Jan Holman van Streuvels' Doodendans, in het Tsjechisch rond 1911 verschenen als Koloběh smrtí (waarschijnlijk) en de vertalingen van Timmermans' werken Anna Maria en De pastoor uit den Bloeyenden Wijngaerdt, respectievelijk in 1934 verschenen als Delfini (vertaling van Quido Palička) en in 1938 als Farár na kvetoucí vinici (vertaling Bedřich Půza) uit het Duits vertaald. In de laatste twee gevallen is dit zelfs expliciet in de vertaling vermeld.
} 
in de jaren vijftig veranderde dit en werd bijvoorbeeld werk van Timmermans systematisch uit de bibliotheken verwijderd.

De Tsjechische positie is daarbij een heel andere dan de Poolse of Hongaarse. Er is tijdens het interbellum maar één streekroman in het Pools vertaald, Het wassende water van Herman de Man (1925), dat in het Pools uitkwam als Wezbrana fala (1939) in een vertaling van Henryk Leśniewski (1874-1940). In het Hongaars kwam Het kindeken Jezus in Vlaanderen van Timmermans (1917) uit als A gyermek Jézus flandriában in een vertaling van de priester-dichter Lajos Harsányi (18831959), en wel al in 1920. Dit is vermoedelijk te danken aan de over het algemeen vrij goede positie van Nederlandstalige literatuur in Tsjechië - tot 1989 werd er in het Tsjechisch méér vertaald dan in het Hongaars, Pools, Sloveens, Slowaaks en Servo-Koratisch bij elkaar. ${ }^{6}$

\section{De streekroman in Nederland en Vlaanderen}

Regionale literatuur kwam binnen het Nederlandse taalgebied eerst en vooral in Vlaanderen op. In Vlaanderen speelden de auteurs rondom het tijdschrift $\mathrm{Van} \mathrm{Nu}$ en Straks dat tussen 1893 en 1901 uitkwam, een belangrijke rol bij de vernieuwing van de Vlaamse literatuur. ${ }^{7}$ Degenen onder hen die romans schreven die zich op het platteland afspelen als Cyriel Buysse (1859-1932) en Stijn Streuvels (ps. van Frank Lateur, 1871-1969) hebben een sterk naturalistische kijk. Hun werk staat onder invloed van Franse naturalisten als Émile Zola en Scandinavische schrijvers als Bjørnsterne Bjørnson en Henrik Ibsen. Met name het werk van Streuvels is in veel talen vertaald. In deze romans speelt vaak de spanning tussen het traditionele platteland en de moderne tijd een rol. Zijn roman De vlaschaard (1907), waarin dit conflict zeer scherp getekend is, is verreweg zijn bekendste werk en werd in verschillende talen vertaald.

Na 1910 komt de boerenroman tot bloei. Van de auteurs van dit type romans zijn Ernest Claes (1885-1968) en Felix Timmermans (1886-1947) goed in Tsjechische vertaling vertegenwoordigd. Vooral Timmermans brak internationaal door met zijn roman Pallieter (1916). Deze levensgenieter kwam mede dankzij het grote aantal vertalingen in meer dan veertig talen samen met Tijl Uilenspiegel bekend te staan als 'de Vlaming.' Timmermans' romantisch-religieuze werken als Het kindeke Jezus in Vlaanderen (1918) en zijn meesterwerk Boerenpsalm (1935) kennen eveneens een vrij omvangrijke internationale receptie.

\footnotetext{
${ }^{6}$ Vgl. Engelbrecht 2010 en 2012.

${ }^{7}$ Voor de Vlaamse streekliteratuur is m.n. M. Dupuis, “De vernieuwing van de romankunst 19131941," in: Rutten en Weisgerber 1988: 441-495 gevolgd.
} 
In Nederland werd de heimatliteratuur niet als 'echte literatuur' beschouwd. Vooral de critici rondom het tijdschrift Forum als Menno ter Braak verweten de schrijvers van streekromans gebrek aan literaire kwaliteit en stijl, een te anekdotische verhaallijn en gebrek aan universaliteit. Het zwaartepunt van de Nederlandse streekliteratuur ligt later dan in Vlaanderen, in het interbellum. Vooral Antoon Coolen (1897-1961) die het harde leven in de Brabantse Peel beschreef, en Herman de Man (ps. van Salomon Herman Hamburger, 1898-1946), wiens Het wassende water (1925) zich in de Utrechtse rivierpolder Lopikerwaard afspeelt, verwierven grote bekendheid. Ook Theun de Vries (1907-2005), A. den Doolaard (ps. van Cornelis Spoelstra, 1901-1994) en Jef Last (1898-1972) schreven romans die tot de streekliteratuur kunnen worden gerekend. Vele werken van hen werden in het Tsjechisch vertaald. Antoon Roothaert (1896-1967) werd bij een groot publiek bekend door de verfilming van zijn Doctor Vlimmen (1936) in 1977. Na de oorlog werd hij als 'fout' beschouwd, omdat de bezetter zijn kritiek op de slechte bewapening van het Nederlandse leger aangreep en zijn boeken als propaganda uitgaf. Roothaert was echter zelf nimmer NSB-lid of lid van de Kultuurkamer (Walch 1996). Na de oorlog was de streekliteratuur in het Nederlandse taalgebied geen bijster productief genre meer. Een late loot aan de stam van de streekauteurs was Toon Kortooms (1919-1999). Net als de romans van Antoon Coolen spelen die van hem zich in de Peel af met Dokter Angelino als protagonist.

\section{Tsjechische Heimatliteratuur ${ }^{8}$}

De heimatliteratuur als zodanig gaat in het Tsjechisch terug tot medio negentiende eeuw. Als grondlegger wordt meestal de priester-schrijver František Pravda (1817-1904) gezien die in 1848 de novelle Dvě svatby najednou (Twee huwelijken tegelijkertijd) uitbracht. Zijn werk doet qua tendentie het meest denken aan Hendrik Conscience. Ook bij hem ligt er in zijn novelles veel nadruk op sociale problemen op het platteland en in de kleine steden, hij legde veel nadruk op christelijke waarden en morele standvastigheid. Zijn werk en dat van schrijvers in zijn trant als de Moravische priester Václav Kosmák (1843-1898), wiens roman Chrt (1888, De hazewind) zeer geliefd was, hadden net als Consciences werk veel succes bij het grote publiek.

Onder de schrijvers in de negentiende eeuw verwierf de schrijfster Božena Němcová (1820-1862) verreweg de grootste internationale bekendheid met haar

\footnotetext{
${ }^{8}$ Deze beknopte beschrijving van de Tsjechische heimatliteratuur en de volgende paragraaf over het ruralisme is gebaseerd op Hora 2009, Novák 1946: 398-414, 670-678 en Putna 2010: 831-922.
} 
roman Babička (1855, De Grootmoeder), ${ }^{9}$ waarin de gevaren van de moderne samenleving die de onbedorven plattelandsbevolking bedreigen worden geschilderd. Realistische schrijvers rondom de almanak Máj (1858, Mei) als de schrijfster Karolina Světlá (1830-1899) situeren hun psychologische romans met voorliefde op het platteland.

Eind negentiende eeuw kwam in reactie op het politieke liberalisme een ideologie op die de boerenstand zag als de ideale morele en maatschappelijke ordening van Tsjechië. De belangrijkste exponent van deze ideologie was Josef Holeček (1853-1929) die daarbij sterk was beïnvloed door Russische theoretici als Nikolaj Jakvlovitsj Danilevski (1822-1885), wiens belangrijkste werk Россия и Европа. Взгляд на культурные и политические отношения Славянского мира к Германо-Романскому (1895, Rusland en Europa. Een blik op de culturele en politieke betrekkingen van de Slavische wereld met de Germaans-Romaanse) ${ }^{10}$ grote invloed had op theoretici en literatoren in andere Slavische volkeren. Holček bundelde in Selství (1928, De boerenstand) zijn eigen theoretische essays, waarin hij de patriarchale boerenstand presenteerde als de belangrijkste morele kracht van het Tsjechische volk. Een soortgelijke ideologie, maar dan in christelijke zin, treffen we aan bij de populaire priester-schrijver Jindřich Šimon Baar (1869-1925) die met zijn roman Jan Čimbura (1908) het type van de katholieke boer schiep. Baar was de grondlegger van het realisme in de Tsjechische literatuur en een voorman van de Katolická moderna (Katholieke Modernen).

Afgezien van Božena Němcová en Jindřich Šimon Baar is met name een derde groep uit deze periode tot op de dag van vandaag populair. Deze groep wordt gevormd door de zogenaamde 'nationale opbouwers' (národní buditele). Zij waren sterk beïnvloed door Russische schrijvers als Tolstoj en Toergenjev of Scandinavische schrijvers als de reeds genoemde Bjørnstern Bjørnson. Het gaat om nationaal voelende, vaak sociaal geëngageerde schrijvers als Tereza Nováková (1853-1912), Jan Herben (1857-1936), de gebroeders Alois (18611925) en Vilém Mrštík (1863-1912) en Karel Veliký Rais (1859-1926) die de idee van de nieuwe onafhankelijke Tsjechoslowaakse Republiek voorbereidden. Zij schilderen in vaak inktzwarte schetsen het plattelandsmilieu aan de grenzen van de staat - het West-Boheemse Chodsko, de Vrchovina (het Boheems-Moravische Heuvelland) of Slovácko (Moravisch-Slowakije) - omstandigheden uit welke de koetsierszoon en eerste staatspresident Tomáš Garrigue Masaryk (1850-1937)

\footnotetext{
${ }^{9}$ Een fragment van de roman is als Grootmoeder. Babička in 2011 verschenen in Tijdschrift voor Slavische Literatuur 60. De vertaler Kees Mercks bereidt een complete vertaling voor.

${ }^{10}$ Eerst verschenen in het tijdschrift Zarya in 1869, dan in boekvorm in St.-Petersburg in 1871. De editie die het vaakste geciteerd werd en ook aan de basis van vertalingen stond is de aangehaalde van 1895. Duitse vertaling Russland und Europa, 1920.
} 
afkomstig was. ${ }^{11}$ De genoemde schrijvers - en de groep zou nog flink kunnen worden uitgebreid - worden in het algemeen gezien als vertegenwoordigers van verschillende stromingen van het realisme (Realismus) dat veel trekjes gemeen had met bepaalde Vlaamse Van Nu en Straksers.

\section{Het Tsjechische ruralisme}

Het ruralisme (ruralismus) kwam op in de jaren dertig van de twintigste eeuw. Het belangrijkste thema was de ingrijpende invloed van de moderne tijd op het tradtionele plattelandsleven en het innerlijke verzet van traditionele plattelandsbewoners daartegen. Die invloed had te maken met kapitalisering van het platteland, de gedeeltelijke herverdeling van grootgrondbezit onder boeren begin jaren twintig, mechanisatie van de arbeid en de trek naar de grote stad, en respectievelijk de verstedelijking van plattelandsgemeenschappen nabij grotere steden.

In ruralistische literatuur treffen we vaak uitgebreide beschrijvingen van het platteland aan met veel aandacht voor traditionele gebruiken. De stad is meestal afgebeeld als een plek van ontmenselijking, waar de plattelander die erheen is getrokken, zijn identiteit verliest. Daartegenover worden het akkerland en de boerengemeenschap gepresenteerd als de belangrijkste bron voor de ordening van de Tsjechische maatschappij. De tegenstelling van het 'zuivere platteland' tegenover de 'verdorven stad' komt wel het sterkst tot uitdrukking in de roman Puklý chrám (De gebarsten kerk, 1937) van František Křelina (1903-1976). De ontwikkelingen worden eerder als dramatisch en tragisch voorgesteld en eindigen meestal met een nederlaag van protagonisten die de traditionele waarden van het platteland verdedigen. Daarmee staan de ruralisten dichter bij een Vlaamse schrijver als Streuvels dan bij de optimist Timmermans. Evenals in de Vlaamse romans is er sprake van een constante wisselwerking tussen het platteland zelf dat als het ware mede-protagonist is en de hoofdpersonen van de romans. ${ }^{12}$

Dit ruralisme was sterk katholiek georiënteerd. Deze richting begon praktisch met Antonín Matula (1885-1953), afkomstig uit de Valašsko (MoravischWalachije), die in zijn boek Hlasy země v evropských literaturách (1933, De stem van het land in Europese literaturen) een overzicht gaf van Europees literair werk met dorpsthematiek - uiteraard kwam hierbij ook de Vlaamse literatuur aan bod - en het begrip ruralisme muntte. In dit boek wordt de "Hollandse" rurale

\footnotetext{
${ }^{11}$ Het is geen toeval dat Herben o.a. biograaf van Masaryk was en redacteur van tijdschriften die politiek met hem verwant waren als Zora.

${ }^{12}$ Vergelijk de karakterisering van beiden bij Van Itterbeek 1976: 20-21.
} 
literatuur als laatste van de buitenlandse streekliteraturen behandeld. Matula noemt expliciet Herman de Man, Het wassende water, Stijn Streuvels, De oogst, De werkman, Langs de wegen, Dorpslucht, De Vlaschaard en Het uitzicht der dingen, en Reijmont Stijn, Hard labeur als typische voorbeelden van streekromans. Felix Timmermans wordt als laatste voorbeeld aangehaald met de opmerking dat zijn optimistische Pallieter atypisch is voor de Vlaamse streekliteratuur. ${ }^{13}$

In zijn essay "Ruralismus v krásném písemnictví" (Het ruralisme in de schone letteren) dat in december 1932 verscheen, gaf Matula definitief de naam ruralisme aan de hele richting en vormde een soort programma voor de stroming. De belangrijkste protagonisten waren de prozaschrijver, dichter en criticus Josef Knap (1900-1973), tevens redacteur van het literaire tijdschrift Sever a východ (Noorden en Oosten) dat tussen 1925 en 1930 uitkwam en de NoordEuropese stijl propageerde, František Křelina, Jan Čarek (1898-1966) en Václav Prokůpek (1902-1974). Ten slotte kunnen ook de katholieke dichters Václav Renč (1911-1973) en Jan Zahradníček (1905-1960) tot de kring van ruralisten worden gerekend, hoewel hun poëzie formeel als spiritualisme wordt aangeduid.

Vrijwel de gehele groep had tijdens de oorlog problemen met de Duitse bezetter. Zo moest Knap als dwangarbeider werken en Křelina was in 1939 als Tsjech gedwongen om zijn geboortegrond, de Sudeten, te verlaten. Maar desondanks konden zij min of meer ongestoord schrijven. Net als in Duitsland vluchtten de katholieke intellectuelen in een innere Emigration of trachtten hun sterke vaderlandse voorkeuren in een allegorische symboliek te verstoppen. ${ }^{14}$ Sommigen probeerden in hun door de bezetter min of meer getolereerde tijdschriften en uitgeverijen de niet-communistische illegaliteit te ondersteunen. Zo werd Václav Prokůpek in 1942 benoemd tot directeur van de coöperatieve katholieke uitgeverij Moravské kolo spisovatelů (Moravische Schrijverskring), met 5000 leden een middelgrote uitgever. De uitgeverij verzorgde regelmatig illegale extra drukken van boeken en financierde hieruit de ondersteuning van familieleden van in concentratiekampen gestopte leden, van geëxecuteerden of van schrijvers die van de bezetter een publicatieverbod hadden gekregen.

Hoewel in 1945 de democratie formeel werd hersteld en Tsjechoslowakije tot 1948 gunstig afstak bij de rest van Centraal-Europa, was er geen sprake van

\footnotetext{
${ }^{13}$ Matula 1933: 45-46. Verderop in zijn werk behandelt hij onder de vertaalde romans Timmermans, Pallieter (Matula 1933: 60) en onder de destijds nog niet vertaalde De Man, Het wassende water (Matula 1933: 66), Streuvels, Jantje Verdure en De Vlaschaard (Matula 1933: 70). In de afdeling "Pohledy do života i díla" (Kijk op het leven en werk) worden ten slotte nog van Streuvels zijn Doodendans, Minnehandel, Lenteleven en De werkman genoemd (Matula 1933: 79), alsmede opnieuw Timmermans, Pallieter (Matula 1933: 80).

${ }^{14}$ Deze methodiek is goed beschreven in Stanislav Balík, "Čeští katoličtí intelektuálové a nedemokratické režimy." (Tsjechische katholieke intellectuelen en ondemocratische regimes). In: Kubíček \& Wiendl 2005: 174-188, m.n. 180-181.
} 
een echte democratie. Zo werd de Agrarische Partij verboden die voor de oorlog tussen 1922 en 1938 altijd deel uitgemaakt had van de coalitieregeringen en meestal als grootste partij de premier had geleverd. De officiële reden was dat deze partij zich te positief had opgesteld jegens de tijdelijke Tweede Republiek, een semi-autoritaire overgangsstaat die was ontstaan na het afstaan van de Sudentenduitse gebieden (1938-1939). De feitelijke reden was dat de agárníci nogal eens de motor waren geweest van het niet-communistische verzet en dus potentieel gevaarlijk waren voor de plannen van de communisten. Veel katholieke schrijvers kregen in 1945 onder het voorwendsel dat zij tijdens de oorlog hadden kunnen publiceren en 'dus' gecollaboreerd hadden, een tijdelijk schrijfverbod. In oktober 1945 verscheen er een artikel in het nauw met het partijblad Právo lidu (Het Recht van het Volk) verbonden culturele tijdschrift Kulturní politika (Cultuurpolitiek), waarin hoofdredacteur Václav Běhounek een hele serie auteurs, onder wie Renč en Zahradníček noemde als "zij die verdacht dicht bij het fascisme staan." (Běhounek 1945) In de meest recente studies over Tsjechisch literatuur wordt de zgn. Derde Republiek (1945-1948) daarom onder het hoofdje "autoritaire regimes" geplaatst.

Na de communistische machtsovername werd het leven voor de katholieke auteurs en de ruralisten steeds moeilijker gemaakt. In 1951 werden vrijwel alle katholieke schrijvers en ruralisten gevangen gezet en in grote communistisch showprocessen in april en juli 1952 veroordeeld. Deze processen waren officieel gericht tegen de Groene Internationale, een door de communistische geheime dienst geconstrueerd complot waarin katholieke intellectuelen op instigatie van het Vaticaan en betaald door de Verenigde Staten via hun literaire werk zouden hebben geprobeerd om de nieuwe arbeiders- en boerenstaat te destabiliseren. ${ }^{15}$ Vrijwel alle auteurs werden met zware folteringen tot ingestudeerde bekentenissen gedwongen. Eén katholiek, de hoogleraar Josef Kepka (1902-1952), werd ter dood veroordeeld, drie auteurs kregen levenslang, vijftien anderen lange gevangenisstraffen voor in totaal 215 jaar. Hun boeken werden in de jaren 19511952 uit de bibliotheken verwijderd, overigens samen met veel vertalingen van Vlaamse auteurs. Veel auteurs werden tijdens de Praagse Lente in de jaren 19671968 gerehabiliteerd en konden weer publiceren. Maar als krachtige beweging had het ruralisme toen al afgedaan - zijn thema en doelpubliek, het traditionele Tsjechische platteland, bestond al niet meer vanwege de collectivisatie die door het nieuwe regime in de jaren vijftig met harde hand was doorgevoerd.

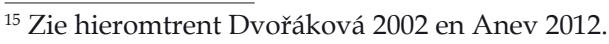




\section{De vertalingen tot en met Wereldoorlog II}

In het hierboven geschetse klimaat kwamen Tsjechische vertalingen van Nederlandstalige literatuur uit. Deze vertalingen hebben in Tsjechië al een tamelijk lange traditie die teruggaat tot halverwege de negentiende eeuw. In het begin was vooral Conscience de topauteur, al treffen we aan het begin van de twintigste eeuw ook vertalingen aan van Van Nu en Straksers als Cyriel Buysse, Herman Teirlinck en Stijn Streuvels. Van alle drie de genoemde auteurs werden novelles opgenomen in de prestigieuze serie 1000 nejkrásnějších novell 1000 světových autorü (1000 mooiste novelles van 1000 wereldauteurs) die tussen 1911 en 1915 uitkwam bij de grote liberale uitgever Jos R. Vilímek in Praag. ${ }^{16}$ Van Streuvels kwam bovendien diens eerste bundel Lenteleven (1899) in 1909 in boekvorm uit als Járo bij de socialistische uitgeefster Kamilla Neumannová in Praag.

In het interbellum nam het aantal vertalingen flink toe, vooral dankzij het werk van Lída Faltová (1890-1944) die zich op het Nederlands toelegde en gedurende haar werkzame leven 42 vertalingen uit het Nederlands uitbracht. ${ }^{17}$ Faltová was huisvertaalster van de coöperatieve uitgeverij Družsteoní práce (De Collectieve Arbeid), die in het interbellum tot de meest toonaangevende literaire uitgevers behoorde. Gezien het feit dat deze uitgeverij zich vooral op de middelklasse richtte en tevens de arbeider cultureel wilde verheffen, waren al te uitgesproken katholieke werken minder gewenst. Faltová vertaalde die wel, maar deze vertalingen kwamen bij andere uitgeverijen uit. Faltová introduceerde de streekliteratuur met Ernest Claes, van wie zij Kobeke (1933, Syn po tátovi, 1936, $1937^{2}$ ) vertaalde en zijn meest bekende roman De Witte (1920, in 1938 samen met Pastoor Campens zaliger, 1935, uitgekomen als Veselé občané Sichemští, herdrukken in 1941 en 1946). In de oorlogsjaren kwam in een vertaling van Faltová nog Het leven van Herman Coenen (1930, Život Heřmana Coena, 1941) uit.

Afgezien van Claes omvatte haar productie eind jaren dertig nog meer streekromans. Van de Vlaamse auteurs kwamen van haar hand vertalingen van de bekendste romans van Streuvels uit: Minnehandel in Vlaanderen (1903, Milování

\footnotetext{
${ }^{16}$ Dit ambitieuze project was geconcipieerd als een literaire encyklopedie van de wereldliteratuur. Elk bandje verenigde drie tot vijf auteurs, waarbij was getracht om een zo typisch mogelijk werk te kiezen. Aan alle werken ging een korte auteursbiografie vooraf. Het project werd wegens papierschaarste tijdens Wereldoorlog I gestopt. Desondanks was de uitgeverij er al in geslaagd om zo'n 500 novelles in 102 afleveringen (34 banden) uit te geven. Van Buysse kwam zijn novelle Het Paard uit de bundel Uit Vlaanderen (1899) uit als Kưn in aflevering 16 (ca. 1911, in dezelfde band stond ook Van Eedens Het krabbetje en de gerechtigheid), van Streuvels kwam De doodendans uit de gelijknamige bundel (1901) uit als Koloběh smrti (ca. 1911) in aflevering 20, en Teirlincks Het lied van Peer Lobbe (1910), opgenomen als Píseň o Peer Lobbeovi (ca. 1913) in bandje 57.

${ }^{17}$ Gegeven het feit dat Faltová in totaal iets meer dan 60 vertalingen maakte, is dit goed tweederde van haar vertaalproductie, zie Engelbrecht 2010: 191-193.
} 
ve Flandř́ch, 1939) en De Vlaschaard (1907, Lništěe, 1942), de eerste bij uitgeverij Evropský literární klub in Praag, de tweede bij haar huisuitgeverij Družstevní práce. Andere vertalers vertaalden nog eens twee romans van Streuvels - Alma met de vlassen haren (1931, Plavovlasá Alma, 1939) en De teleurgang van den Waterhoek (1927, Velký most, 1943). Faltová kampte toen al met schildklierproblemen, waaraan zij uiteindelijk aan een mislukte operatie in 1944 zou overlijden. Bovendien had zij geen geluk in haar privéleven. Haar echtgenoot, een belangrijke sociaaldemocratische politicus, was in 1939 naar de Verenigde Staten in ballingschap gegaan, vanwaar hij de Council of Free Czechoslovakia leidde. Haar zoon was direct na zijn eindexamen gearresteerd en bleef tot het eind van de oorlog geïnterneerd.

Onder de door Faltová vertaalde Nederlandse streekromanschrijvers is Antoon Coolen vertegenwoordigd met De vreemdeling (1935, Cizinec, 1936), Kinderen van ons volk (1928, Romance $z$ Brabantu, 1937) en zijn verreweg bekendste streekroman Dorp aan de rivier (1934, Ves u řeky, 1937). Dit laatste werk was een regelrecht kassucces en werd in Tsjechië in 1940 herdrukt en vervolgens samen met een vertaling van De drie gebroeders (1936, eerst apart vertaald als Tři bratř́, 1939) uitgebracht in de bundel Vesnický lékař (letterlijk: De dorpsdokter, 1942), die nog driemaal uitkwam $(1944,1946,1968)$. De goede moordenaar (1931) werd in 1939 gepubliceerd (Dobrák vrah), een ander kassucces Herberg in 't Misverstand (1938) als Hospoda U Nesvaru in 1942 (herdruk 1970). Verder vertaalde zij nog De schoone voleinding $(1932$, Koruna života, 1943) en tenslotte nog De Peelwerkers (1930) dat na haar dood uitkwam in 1946 als Rašelinaři. Van Jef Last vertaalde zij behalve diens boek In de loopgraven voor Madrid (1937, V zákopech u Madridu, 1937) ook diens streekroman Zuiderzee (1934, Zuiderské moře, 1936). Van Herman de Man tenslotte vertaalde Faltová diens bekendste boek Het wassende water (1925, Voda stoupá, 1938).

Omdat de vraag naar vertalingen van Coolen groter was dan Faltová aankon, werden sommige romans door een ander vertaald. Coolens roman Het donkere licht (1929) kwam in 1942 als Temné světlo uit bij Plzákovo nakladatelství te Praag (herdruk 1946) in een vertaling van de hand van Rudolf Jordan Vonka (18771964). Hiermee komt een van de meest markante vertalerspersoonlijkheden uit het interbellum in beeld. Vonka was geen beroepsvertaler zoals Faltová, maar deed de vertalingen er uit liefhebberij bij. Hij behoorde tot de groep activistische leraren die zich eind negentiende en begin twintigste eeuw sterk maakten voor de Tsjechische cultuur en later voor de onafhankelijke staat. In 1920 kwam Vonka in dienst van het Ministerie van Buitenlandse Zaken in Praag en werd al spoedig uitgezonden naar Nederland, waar hij van 1920 tot 1924 op de ambassade in Den Haag werkte. Vonka was gelovig protestant en actief vrijmetselaar en behoorde 
tot degenen die in de jaren twintig van de twintigste eeuw in Naarden op zoek waren naar het graf van Comenius. ${ }^{18}$ Zijn interesse voor Comenius en diens verblijf in Nederland en zijn werk op de ambassade in Den Haag maakten dat Vonka en zijn vrouw Linda Vonková-Chmelařová (geb. 1884) beiden Nederlands leerden. Tijdens de oorlog was Vonka actief in de verzetsgroep Věrný pes (De trouwe hond) en werd meermalen door de Gestapo opgepakt. In 1948 behoorde hij tot de ondertekenaars van het manifest Provolání politických a kulturních představitelü $k$ československé veřejnosti (Oproep van politieke en culturele vertegenwoordigers aan het Tsjechoslowaakse publiek) dat op 21 en 22 februari verscheen en president Beneš opriep om ogenblikkelijk vrije democratische verkiezingen te organiseren. ${ }^{19}$ De meeste ondertekenaars werden later gestraft, maar Vonka had zich bijtijds teruggetrokken.

Vonka vertaalde niet zoveel: er zijn negen vertalingen van zijn hand uit het Nederlands bekend. In 1927 kwam van Vonka's hand bij Družsteoní práce een vertaling van Pallieter van Felix Timmermans (1916) uit. De vertaling verkocht kennelijk goed en de uitgeverij besloot om ook Pieter Breugel, zo heb ik uit uwe werken gerooken (1928) uit te geven. Deze vertaling, Petr Breugel. Co jako vuině zavánělo z jeho díla kwam in 1934 uit en werd meermalen herdrukt (1935, 1940, 1971). Een derde werk van Timmermans, Boerenpsalm (1935) kwam in 1938 als Selský žalm uit in de prestigieuze serie Symposion van de gelijknamige uitgeverij van Rudolf Škeřík in Praag (herdrukken 1940, 1941 en 1948). Vrij snel daarna gaf Vonka Het kindeke Jezus in Vlaanderen (1917) in Tsjechische vertaling als Ježišek ve Flandřích uit bij Julius Albert in Praag, waar voor de oorlog meer Nederlandstalig werk in vertaling was verschenen.

Tijdens de oorlogsjaren vertaalde Vonka nog De familie Hernat (1941) dat al in 1943 bij Symposion verscheen onder de neutrale titel Rodinná kronika (Een familiekroniek). Van Timmermans' werk werd nog meer vertaald: Otto F. Babler (1901-1984), bibliothecaris te Olomouc en polyglot, vertaalde De zeer schone uren van juffrouw Symforosa, begijntje (1918) dat in 1929 als Krásné čtení o panně Symforose uitkwam; een andere polyglot, Otakar Fischer (1883-1938) gaf in Vánoce ve Flandřích een verzameling kerstverhalen van Timmermans uit; bij Symposion kwam in 1933 De harp van Sint Franciscus uit onder de titel Prostáček Boží (herdruk 1942); Anna Marie (1921) werd door Quido Palička (1892-1962) volgens mededeling op de titelblad op uitdrukkelijk verzoek van de auteur uit

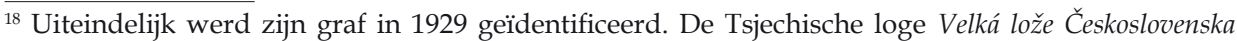
financierde een groot deel van de renovatie van de kapel van de voormalige Waalse kerk. Nu is hier het Comeniusmuseum gevestigd.

${ }^{19}$ Een van de organisatoren was Vojtěch Beneš (1878-1951), een oudere broer van de president. Zie Václav Veber, "Vojta Beneš ve třetím odboji." Pamět a dějiny 2010, nr. 2, p. 109-122 (de oproep is aangehaald op p. 111.
} 
het Duits vertaald (!) als Delfini (1934, herdruk 1945), en ten slotte kwam nog De pastoor uit den Bloeyenden Wijngaerdt eveneens in een vertaling via het Duits in 1938 in Brno uit als Farář na květoucí vinici.

Net als in Duitsland was de grote vraag naar Nederlandstalige literatuur - en dan vooral die van katholieke, niet-nazistische signatuur - tijdens de Tweede Wereldoorlog in Tsjechië ingegeven door een poging om het wegvallen van de mogelijkheid om Engelstalige literatuur uit te geven te compenseren. ${ }^{20}$ De censor stond streekliteratuur meestal toe in de gedachte dat dit overeenkwam met de officiële Blut und Boden ideologie. Timmermans was bovendien een in Duitsland gevierde auteur.

\section{Vertalingen na Wereldoorlog II}

$\mathrm{Na}$ de oorlog kregen de Tsjechische ruralisten vrijwel direct problemen. Hierboven hebben we aan de jaartallen van herdrukken kunnen zien dat dit vooreerst niet gold voor streekliteratuur in vertaling. Er kwamen verschillende herdrukken van vertalingen uit die voor of tijdens de oorlog waren verschenen. Tot 1948 kwamen er bovendien ook nieuwe vertalingen uit van werk van Antoon Coolen en Stijn Streuvels. De romanist Miroslav Drápal (1916-1991) die ook Nederlands kende, vertaalde in 1948 als zijn eerste boek uit het Nederlands Coolens Peerke dat manneke (1926) dat als Peerke strašpytel uitkwam bij uitgeverij Sfinx te Praag. Ook een andere vertaalster maakte haar debuut met Coolen. Ella Kučerová (1909-1982) die zich na haar huwelijk met dr. Jaroslav Kazda toelegde op het vertalen van Nederlandstalige literatuur, ${ }^{21}$ vertaalde Coolens Uit het kleine rijk als Z malého království (1948) voor de in 1945 opgerichte uitgeverij Mladá fronta (Het jonge front). Bij een kleine uitgeverij in het Zuid-Boheemse Blatná kwam Langs de wegen (1902) van Streuvels uit als Cesta vede k domovu (1946). Een verklaring voor dit feit is dat de zogenaamde regering van nationale eenheid nog veel democratische leden bevatte en dat de communistische ministers - mede vanwege de grote stemmenwinst van $40 \%$ bij de eerste naoorlogse verkiezingen - eerst van mening waren dat het mogelijk was om langs geleidelijke weg de macht te grijpen. Zij wilden de regeringspartners, bij wier uitgeverijen deze vertalingen uitkwamen, niet voor het hoofd stoten én naar het westen toe een democratisch gezicht tonen.

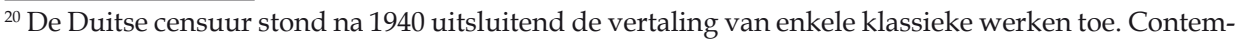
poraine "vijandelijke auteurs" waren verboden. Zie Masnerová 2002: 51.

${ }^{21}$ Voor Kazdová zie "Ela Kučerová," op Filmová database online FDb.cz, www.fdb.cz/lidi-zivotopisbiografie/55625-ela-kucerova.html (download 13 juli 2012; correctie sterfjaar op basis van de gegevens van de nationale bibliotheek NKP).
} 
$\mathrm{Na}$ het geconstrueerde proces tegen de Groene Internationale was de streekliteratuur als zodanig, dus ook die in vertaling verdacht geworden. Werk van Ernest Claes, Felix Timmermans en Stijn Streuvels werd begin jaren vijftig als "te religieus" of "ongeschikt voor de jeugd" uit de bibliotheken verwijderd (Šamal 2009). ${ }^{22}$ Ook hun boeken konden al te zeer een beeld geven van een plattelandsamenleving buiten de door de communisten gepropageerde kolchozen, in Tsjechië Jednotné zemědělské družstvo of gemeenzaam JZD (Coöperatieve Landbouwgemeenschap) genoemd, en waren dus ongewenst. Het is geen toeval dat pas met de Praagse Lente, toen veel schrijvers van de ruralisten gerehabiliteerd of vrijgelaten werden, een klein golfje herdrukken en vertalingen van Nederlandstalige streekromans opkwam. ${ }^{23}$

Er is echter één interessante uitzondering. Bij de uitgeverij van de gelijknamige, als 'juniorpartij' getolereerde katholieke volkspartij, die tussen 1948 en 1989 onder de neutralere naam Lidová demokracie (Volksdemocratie) fungeerde, kwam in 1958 De heiligen van Sichem van Ernest Claes uit 1931 als U nás v Sichemu uit. Dankzij het feit dat onder het communisme van alles werd geregistreerd, weten we dat de oplage 13.000 stuks was, voor die dagen een flinke oplage, zeker voor een uitgeverij als Lidová demokracie. De uitgeverij was al in 1911 opgericht als Českoslovanská akciová tiskárna (Tsjechoslowaakse Aandeelhoudersdrukkerij) en drukte materaal en literatuur voor katholieke partijen. In 1934 was als literaire uitgeverij door de ČAT een apart uitgevershuis Vyšehrad gesticht dat na de oorlog eerst de naam Universum kreeg en in 1953 werd samengevoegd met de drukkerij Lidová demokracie. Voor de oorlog was een groot deel van de productie van katholieke auteurs, onder wie ook ruralisten, door Vyšehrad uitgegeven. Vrijwel alle auteurs die in 1951 waren veroordeeld, hadden hier hun werk uitgegeven, wat de uitgeverij in communistische ogen bepaald verdacht maakte en reden was om de naam in 1953 te wijzigen. Met de Praagse Lente kreeg de uitgeverij haar oorspronkelijke naam Vyšehrad weer terug, die zij tot op heden draagt.

De Praagse Lente zorgde voor omstandigheden die niet alleen de Tsjechische ruralisten, maar ook streekliteratuur in vertaling publicatiemogelijkheden gaven. Lidová demokracie was er met de vertaling Spoutaná voda van Het verjaagde water (1947) van A. den Doolaard door Ella Kazdová die inmiddels veel voor deze uitgeverij vertaalde in 1964 vroeg bij. Er kwamen overigens nauwelijks nieuwe vertalingen uit. Van Coolen werden in 1968 twee werken herdrukt (De drie gebroeders. Dorp aan de rivier, oplage 160.000 stuks) en 1970 (Herberg in 't Misverstand, 40.000 stuks), van Timmermans werd in 1971 zijn roman over Pieter

\footnotetext{
22 Šamal 2009 geeft ook een editie van communistische verwijderingslijsten.

${ }^{23}$ Dit past ook in het positieve beeld dat Smolka 2011: 46-49 schetst voor deze periode.
} 
Breugel herdrukt - overigens strikt genomen geen streekliteratuur. ${ }^{24}$ Kazdová vertaalde voor Vyšehrad nog De oude klok (1947) van Ernest Claes dat als Staré hodiny in 1972 werd gepubliceerd in een oplage van 20.000 stuks. De hoge oplagen voor Coolen zijn te danken aan de opname van de titel Vesnický lékař in het fonds van een boekenclub, waarvoor oplagen tussen de 100.000 en 200.000 stuks normaal waren. De gemiddelde oplage was in Tsjechië destijds rond de 43.000 stuks.

Een late loot aan de stam van de streekliteratuur was de schrijver Toon Kortooms (1916-1999), wiens romans zich vaak in de Brabantse Peel afspelen. Bij Vyšehrad kwamen drie romans van hem uit: Help de dokter verzuipt! (1968) als Pomóóóc! Doktor se topí... (1978, 20.000 stuks, herdrukken 1992 en 2001), Laat de dokter maar schuiven (1975) als Doktor to zařídi (1981, 25.000 stuks) en ten slotte nog Laat de dokter maar opkrassen (1980) als At'už doktor kouká mazat (1985, 45.000 stuks), de eerste twee vertalingen door Ella Kazdová, de laatste door Olga Krijtová (1931-2013), die na de oorlog met ruim 80 vertalingen de belangrijkste vertaler van Nederlandstalige literatuur zou worden. Na de Fluwelen Revolutie van 1989 bracht Vyšehrad in 1994 nog een vierde titel van Kortooms, Parochie in de Peel (1952) uit als Farnost na blatech in een vertaling van Jitka Růžíčková, ex-studente van Krijtová. In vergelijking met de situatie in het interbellum was het aandeel van de streekromans echter verwaarloosbaar: nog geen 5\% van de tussen 1949 en 1989 uitgegeven vertalingen uit het Nederlands behoorden tot deze categorie.

\section{Conclusie}

De vrij grote hoeveelheid vertalingen van Nederlandstalige streekromans in het Tsjechisch is tamelijk uniek voor Centraal-Europa buiten het Duitse taalgebied. Op enkele titels na werden alle werken rechtstreeks uit het Nederlands vertaald, een gevolg van het feit dat er in het interbellum verschillende vertalers werkzaam waren die het Nederlands actief beheersten. Omdat vrijwel alle genoemde auteurs in het Duits werden vertaald en Tsjechische uitgeverijen ook volgden wat er bij hun westerburen uitkwam, kan dit een rol kan hebben gespeeld voor hun receptie in Tsjechische vertaling. Desondanks lijkt de Tsjechische receptie voor Nederlandstalige streekromans vooral parallel te lopen met de lotgevallen van de eigen streekliteratuur. Van het feit dat bijvoorbeeld Antoon Coolen wegens zijn uitdrukkelijk weigering om met het nationaalsocialisme samen te werken na 1941 niet meer in Duitsland werd uitgegeven (Van Uffelen 1993: 298-299), trokken de Tsjechische uitgevers zich weinig aan.

\footnotetext{
${ }^{24}$ Olga Krijtová vertaalde in 1970 Timmermans' posthuum in 1947 uitgekomen schildersroman Adri-
} aan Brouwer. 
Opmerkelijk is de zeer massieve propagering van Nederlandstalige streekliteratuur tijdens de Duitse bezetting. Deze loopt parallel met pogingen van katholieke auteurs om via concentratie op de traditionele waarden van het Tsjechische platteland tegenwicht te bieden aan de onderdrukking door de bezetter van de Tsjechische cultuur. Vooral Coolen en Streuvels werden duidelijk door de uitgevers als passend in deze Tsjechische tendentie gezien. Daarnaast vulde de Nederlandstalige literatuur in vertaling het gat op dat het verbod op de uitgave van destijds als "vijandelijke literatuur" gekenmerkte Engels- en Franstalige auteurs had geslagen.

Terwijl de eigen auteurs van streekliteratuur al direct na de bevrijding het publiceren onmogelijk werd gemaakt, kwamen er in de jaren 1946-1948 wel verschillende vertalingen van Nederlandstalige streekauteurs uit. $\mathrm{Na}$ de showprocessen tegen de zogenaamde Groene Internationale deelde de Nederlandstalige streekliteratuur het lot van de Tsjechische ruralisten. Boeken van Claes, Coolen, Streuvels en Timmermans werden uit de bibliotheken verwijderd en er konden geen nieuwe vertalingen meer uitkomen. Na de Praagse Lente treffen we ten slotte een kleine opleving van de streekliteratuur in vertaling aan.

\section{Literatuur}

Anev, Petr. 2012. "Procesy s údajnými přisluhovači Zelené internacionaly." Pamět a dějiny 4: 23-34.

Běhounek, Václav. 1945. “Co hledají v české kultuře?” Kulturní politika 1, nr. 8.

Čechůrová, Jana. 2002. Čeští svobodní zednáři ve XX. století. Praha: Libri.

Dvořáková, Zora. 2002. Navzdory nenávišti a mstě: z politických procesů 1952 až 1953.

Třebíč: Tempo.

Engelbrecht, Wilken. 2010. “Von Conscience bis Fabricius: Das Bild der niederländischsprachigen Literatur in tschechischer Übersetzung in der Zwischenkriegszeit." An der Schwelle. 'Eigen' und 'fremd' in der niederländischen Literatur. Eds Herbert van Uffelen, Dirk de Geest, Susan Mahmody, en Pieter Verstraeten. Wien: Praesens Verlag. 181-198.

2012. "Van lezerscanon naar gestuurd canon: Literaire vertalingen van

Nederlandstalige literatuur in Tsjechië." Lage landen, hoge heuvels. Handelingen Regionaal Colloquium Neerlandicum Belgradi. Eds Jelica Novaković-Lopušina, Tamara Britka, Bojana Budimir, Mirko Cvetković, en Lada Vukomanović. Belgrado: Arius. 111-127.

Faassen, Sjoerd van. 2003. "“Ik sluit me steeds meer in mezelf op en alleen de buitenlanders interesseren me': Theun de Vries en het debat over het 'Europees peil' van de Nederlandse literatuur in de jaren dertig." Vervolg je weg en laat de lui maar dazen! Theun de Vries, getuige van een eeuw. Eds D. Cartens, en Muriël Steegstra. Amsterdam: Querido. 97-111. 
Geest, Dirk de, Wiel Kusters, Tom Sintobin, en Eveline Vanfraussen. 2005. "Streekliteratuur in Vlaanderen en Nederland: een probleemstelling." Spiegel der Letteren 47 (2): 89-98.

Hora, Petr. 2009. “Von der Ideologie des Bauerntums zur Ideologie des Kollektivismus: Das Thema des Bauernlandes in der tschechischen Literatur der ersten Hälfte des 20. Jahrhunderts." Van Uffelen et al. 119-132.

Itterbeek, Eugène van. 1976. "Sociologische benadering van enkele typen van Vlaamse streekromans." Literatuur in sociaal perspektief. Lezingen gehouden op het symposium van 6 april 1974 te Leeuwarden/Ljouwert, georganiseerd door de Ynteruniversitaire Stúdzjerie Frysk. Ed. A. Feitsma. Amsterdam: Rodopi. 19-46.

Knuvelder, G.P.M. 1982 [10e druk, eerste uitgave 1962] Beknopt handboek tot de geschiedenis der Nederlandse letterkunde. Den Bosch: Malmberg.

Krijtová Olga, Ruben Pellar, en Petra Schürová, eds. 1994. Bibliografie překladů z nizozemštiny do češtiny a slovenštiny od roku 1890 do roku 1993/Bibliografie van vertalingen uit het Nederlands in het Tsjechisch en Slowaaks vanaf 1890 tot 1993. Praha: Jednota tlumočníků a překladatelů.

Kubíček, Tomáš, Jan Wiendl, eds. 2005. Víra a výraz. Sborník z konference '...bývalo u mne zotvíráno...': Východiska a perspektivy české křestanské poezie a prózy 20. století. Brno: Host.

Masnerová, Eva. 2002. “České překlady z anglické a americké literatury." Kapitoly z dějin českého překladu. Ed. Milan Hrala. Praha: Karolinum. 31-51, 71-75.

Matula, Antonín. 1932. "Ruralismus v krásném písemnictví." Osvěta venkova 4 (32-33): 19-26.

1933. Hlasy země v evropských literaturách. Praha: Svobodné učení selské.

Novák, Arne. 1946. Stručné dějiny literatury české. Olomouc: Promberger.

Oversteegen, J.J. 1970 [2e druk, eerste uitgave 1969]. Vorm of vent. Opvattingen over de aard van het literaire werk in de Nederlandse kritiek tussen de twee wereldoorlogen. Amsterdam: Athenaeum-Polak \& Van Gennep. <http://www.dbnl.org/tekst/ over018vorm01_01/>.

Putna, Martin C. 2010. Česká katolická literatura v kontextech: 1918-1945. Praha: Torst.

Rutten, M., en Jean Weisgerber, eds. 1988. Van Arm Vlaanderen tot De voorstad groeit: De opbloei van de Vlaamse literatuur van Teirlinck-Stijns tot L.P. Boon (18881946). Antwerpen: Standaard Uitgeverij. <http://www.dbnl.org/tekst/ rutt006vana01_01/>.

Smolka Fruhwirtová, Lucie. 2011. Recepce nizozemské literatury v českém literárním kontextu let 1945-2010. Olomouc: Univerzita Palackého v Olomouci.

Šámal, Petr. 2009. Soustružníci lidských duší. Praha: Academia.

Uffelen, Herbert van. 1993. Moderne niederländische Literatur im deutschen Sprachraum 1830-1990. Münster: LiT. <http://www.dbnl.org/tekst/uffe003mode01_01/>.

Uffelen, Herbert van, Dirk de Geest, Christine Hermann, en Hilde Moors, eds. 2009. Heimatliteratur 1900-1950 - regional, national, international. Wien: Praesens Verlag. Walch, Frans. 1996. Roothaert. Een biografie. Baarn: De Prom. 